\title{
Race and (the Study of) Esotericism
}

\author{
Justine Bakker
}

The case I wish to make in this essay is simple: race matters in and for the study of esoteric ideas and practice. And how could it not? Esotericisms do not develop in a vacuum, but in particular social, cultural, religious, economic and political contexts. These contexts continue to be marked and shaped by-and in turn inform - what W.E.B. Du Bois so incisively called the "color line."1 Developed in 1903 in The Souls of Black Folk but still poignant, Du Bois coined this phrase to name the visible and invisible lines of demarcation between racial groups. Even as "race is an idea, not a fact," as Nell Irvin Painter (2010, p. ix) famously and concisely put it —and even as racial categories are fluid constructs and not static, fixed identities (Omi and Winant, 1994) - the color line continues to have real-life consequences. This includes explicit forms of racism, like violence and political disenfranchisement, along with implicit racial biases. Examples of such biases are the pervasive inequality in employment, education, health care, and housing, as well as a continued imbalance in the academy when it comes to the study of the history, present, and potential futures of white people and people of color. Racism thus operates in and through systems and structures - and not merely on the level of individual beliefs or actions - that offer advantages for certain racial groups, and disadvantages for others. Racial discrimination comes, moreover, in ever-new forms, and manifests in ever-new ways-in our contemporary moment, such manifestations are often masked or hidden under the guise of the "post-racial" and various forms of "color blindness" (see, among many others, Alexander, 2010; BonillaSilva, 2003; Goldberg, 2015). The "color line" is, therefore, neither stable, static nor fixed, nor is it always easily recognizable, nor is its influence always immediately apparent.

There seems to be, then, a rather obvious rationale for why perspectives on race matter in and for the study of esotericism. A focus on race will help us to better understand some of the contexts out of which past and present esotericisms emerged, thereby shedding light on why and how certain esotericisms are the way they are. In turn, the study of the intersections of race and esotericism might proffer a new vantage point from where to study processes of

1 Du Bois spoke primarily about the United States, but later scholars have expanded this notion as the "global color line" (Marable and Agard-Jones, 2008; see also Wynter, 2003; Sharpe, 2016). 
racialization and racial formation. ${ }^{2}$ Despite this rationale, until recently race was largely ignored in the field of $\left(\right.$ Western $\left.^{3}\right)$ esotericism. Certainly, scholars have studied the connections between forms of white supremacy and esotericism (see e.g. Gardell, 2003; Goodrick-Clarke, 1985; 2001; Staudenmaier, 2014). Yet, the intersections between esotericisms and less obvious formations of whiteness remain to be investigated. And certainly, the edited volume $E s$ otericism in African American Religious Experience (2015) engaged the ways in which African American forms of esotericism wrestle with, resist, or transcend processes of racialization. Yet, the editors of this volume did so explicitly in the context of a new research field, Africana Esoteric Studies, thereby also advancing a necessary critique of the adjective "Western."

And thus, my claim stands: only a handful of texts in (Western) esotericism interrogate the intersections of race and esotericism (Gray, 2019; Knight, 2019; Bakker, 2020). I will turn to the question of why and the implications of this lack towards the end of this essay. However, the bulk of the chapter contributes to efforts that remedy this lacuna by looking at two case studies, both based in the United States. The first engages the phenomenon of what Patrick Polk (2010, p. 26) calls "racialized spirits." I compare the visit of famous Sauk leader Black Hawk at a white séance with that of president Abraham Lincoln at a séance attended solely by black men to ask how constructions of "whiteness," blackness" and "Indianness" are formulated, produced, reinforced, or transcended in and through Spiritualist séances. My second case study tackles the relationship between esotericisms and racialized social location from a different and less obvious vantage point: UFO abduction narratives. In both instances, I make frequent use of secondary literature to demonstrate that although a focus on race certainly is a relatively "new perspective" in the field of (Western) esotericism, it is not foreign to scholarship on esoteric ideas and

2 Racialization is a term frequently used, and in various ways. In this essay, I follow Vincent Lloyd (2016, p. 4), who define racialization as the "sets of ideas, institutions, practices and technologies that establish and maintain a racial regime." "Racial formation," first developed by Michael Omi and Howard Winant (1994), refers to the sociohistorical processes by which racial categories are made and unmade, produced and altered, reinforced and destroyed.

3 I use parenthesis when talking about the field of (Western) esotericism to acknowledge recent scholarship that has explicitly called for the dismissal of the adjective "Western" (see Granholm, 2013; Asprem, 2014; Roukema and Kilner-Johnson, 2018; Strube, 2021). In a recent essay, I joined efforts that query and challenge "Western"; however, I also see value in temporarily keeping the adjective, when used in a self-conscious way, to signal, problematize, and study how the adjective, in and for the study of Western esotericism, has functioned as a racialized category (Bakker, 2019). 
practice conducted in other fields. My engagement with secondary literature shows, too, that there is not "one" perspective on race; a focus on race may in fact yield very different and sometimes even contradictory interpretations. In my conclusion, I make a case for further methodological and theoretical diversification in the field of (Western) esotericism.

\section{$\mathbf{1}$ \\ Racialized Communication with the Dead}

In September 1874, the spirit of Abraham Lincoln (1809-1865) manifested at the séance table of the Cercle Harmonique, a Spiritualist group in New Orleans comprised of black men. The timing, as Emily Suzanne Clark writes, was significant: the city was "on the brink of racial violence" when Lincoln came to "lament" the bloodshed of the city's black inhabitants and "warn" those who advocated white supremacy (2018, p. 161-2). Lincoln often frequented the group and was, as it turns out, not the only famous visitor. From their beginnings in 1858 until their final meeting in 1877 , the members of the Cercle Harmonique - of which Henri Louis Rey (1831-1894) was the most prominent - convened on a weekly basis and welcomed a wide variety of spirits. Philosophers Voltaire (1694-1778) and Montesquieu (1689-1755), abolitionist John Brown (1800-1859), confederate leader Robert E. Lee (1807-1870) and even Pocahontas, famous daughter of Native American chief Powhatan (c. 1596-1617) appeared at the men's table to deliver a message of egalitarianism and reform. In Clark's A Luminous Brotherhood (2016) we read that the spirits formed a collective that imagined "a more egalitarian United States" (p. 4). In an effort to implement what they called "the Idea" - an "egalitarian republicanism" that Clark summarizes as "humanitarian progress, equality, egalitarianism, brotherhood, and harmony" - the spirits acted as teachers, guiding members of the Cercle Harmonique in their efforts for social reform and opposition to the destructive forces of white supremacy (Clark, 2016, p. 5). There remained, after all, as Clark also notes, an enormous difference between the egalitarian, non-hierarchical world of the spirits, and the racialized, if not racist, material world that formed the immediate surroundings of the Cercle Harmonique.

Almost twenty years earlier, and fifteen hundred miles to the north, the spirit of another famous person showed up at a séance table. Black Hawk $\left(1767^{-1838)}\right.$ manifested for the first time during a séance in New York conducted by two sisters named Jennie and Annie Lord in 1857. In his lifetime, Black Hawk was an important Sauk leader who resisted white oppression in Illinois and what is now Wisconsin during what is now called the Black Hawk 
War of 1832. However, his spirit, which subsequently also manifested through other mediums, most often spread a "benevolent" message that "symbolized a cosmic level of peaceful relationships between Indians and whites" (Troy, 2017 , p. 39). ${ }^{4}$ Appearing, in particular, in the 186 os and 1870 , "Indian spirits" often spread a message of a "peaceful relationship" and came in the spirit of forgiveness and reconciliation (McGarry, 2008, pp. 78-79; Cox, 2003; p. 198, p. 206-8). Scholars have argued that we cannot understand the presence of "Indian spirits" outside of policies designed to exterminate, segregate, or "civilize" living Native Americans (Cox, 2005; McGarry, 2008; Bennett, 2007; Troy, 2017). "Amongst the vast throngs of American mediums," Emma Hardinge Britten once wrote, "there is scarcely one who has not at some time or other been controlled, and that most beneficially, by Indian Spirits" (1892, p. 289). It is not a stretch, then, to suggest that as living Native Americans "vanished," they came to "haunt" white Spiritualist séances (McGarry, 2008, p. 66; Bennett, 2007, p. 12; Cox 2003, p. 19o; cf. Troy, 2007, p. xvii).

Surveying the scholarship of Clark, Troy, McGarry, Bennett, and Cox-who work in fields such as (African) American religion and literary studies and thus, it begs repeating, outside of the field of Western esotericism-it becomes immediately evident that when it comes to communication with the dead, race is often not far away. We can approach the intersections of race and Spiritualism from a variety of vantage points. For instance, we could investigateas Alex Owen has done so expertly in relation to gender (1989) - the complicated issue of agency (on the part of mediums and/or spirits). In this essay, however, I want to shed a comparative light on how the racialized manifestation of spirits—or lack thereof-in and during the séances of the Cercle Harmonique and selected examples in white American Spiritualism-produces, reinforces, transforms, or transcends racial constructs. The analysis that follows below is, by necessity, incomplete and simplified; what it demonstrates, however, is that Spiritualism has a racialized history that has been investigated in and from other disciplines and should be further interrogated in the field of (Western) esotericism. As will become evident, the members of the Cercle Harmonique and the white Spiritualists I will discuss had very different understandings of the significance and presence of race in the afterlife. What are we to make of these differences? How did race "show up" at the séance table? And

4 Although I focus here solely on manifestations of Black Hawk at the séances of late nineteenth-century white Spiritualists, I should note that in black Spiritualist churches, where the spirit of Black Hawk was and is also a frequent visitor, he is generally seen as a symbol of resistance against oppression, subjugation, and domination (Guillory, 2018; Troy, 2017; Wehmeyer, 2010). 
what can this tell us about the "color line" in the second half of the nineteenth century?

To begin to answer these questions, I turn to prominent white Spiritualist Benjamin Coleman's Spiritualism in America, published in 1861. When Coleman attended a séance conducted by one of the Lord sisters, Black Hawk manifested. The spirit spoke in "broken English," Coleman writes, offering the statements "Me do something else for you" and "How you do, Mr. Coleman" as evidence (Coleman, 1861, p. 11-12). Black Hawk played one of the many instruments standing in the room, a tambourine, which he "jingled" in "the wildest manner" before proceeding to give an "Indian dance" during which, Coleman notes, "the dull heavy bumping and thumping sounds as if feet in moccasins, or Indian slippers, kept excellent time" (p. 11). Coleman's conclusion is jubilant: "the whole exhibition," he writes, "was a most marvellous and convincing proof of the presence of intelligent invisible agencies" (p. 12).

As Robert Cox writes, most white Spiritualists believed that race was maintained in the afterlife because they saw it as one of the strongest parts of one's identity, a "manifestation" of an "interior" state (Cox, 2003, p. 192). Reading Coleman's account, it becomes evident however that it could show up in very specific ways: in the form of racial stereotypes. The séance that Coleman attended was not an exception. As Troy (2017), McGarry (2008), and Bennett (2005; 2007) demonstrate, "Indian spirits" often manifested in highly racialized and stereotypical ways. Even if the majority of white American Spiritualists critiqued US policy as it related to the "Indian question" and lamented the murder of Native Americans in their periodicals, they also engaged in modes of racial stereotyping that suggest a belief in the cultural superiority of white people. Some white American Spiritualists believed, for instance, that "Indian spirits" resided in the lower realms of heaven, imagined as a "happy hunting ground" where they could continue to use their "traditional" customs and tools (ibid., p. 193). This conceptualization of Native American (after)life — and, in particular, that only "Indian spirits" resided here-perpetuates, in turn, racial stereotype and bespeaks that white people saw themselves as more technologically and culturally "advanced." Not only did race transcend death; racial hierarchies did so, too. To complicate matters further, supposed cultural inferiority did not necessarily imply spiritual inferiority, as there were other white Spiritualists, such as Eugene Crowell and Charles Hammond, who conveyed that "Indian spirits" were morally superior and occupied the highest spiritual realm (Cox, 2003, p. 194). Molly McGarry highlights, in turn, that some white Spiritualists saw "Indian spirits" as "powerful spiritual predecessors" that could function as spiritual guidesshe notes, too, however, that this reverence of Native American forms of spir- 
ituality could easily translate into "unchecked cultural appropriation" (2008, p. 67).

There is considerable debate on how to interpret these stereotypes. For Troy, racial stereotypes were part of, in fact even necessary for, the process of "authenticating": speech patterns, movements, gestures, and dress helped mediums ensure their audience that the spirits they invoked were real (p. xix, 26-30, 65-68). "Mediums," Troy concludes "could not, in essence, break new ground in stereotype construction without first playing upon accepted ones" (p. 7). Cox, however, arrives at a different interpretation. Speaking of "becoming" or "being" "Indian" and utilizing Philip Deloria's well-known concept of "playing Indian," he suggests that "white medium" and "red spirit" seemed to merge, such that the audience "experienced a true interracial fusion, if only vicariously" (2003, p. 203). ${ }^{5}$ This "fusion" was accompanied by "signifiers of cultural inferiority," however, implying that these séances involved a "declaration" of white superiority and, upon returning in/to white skin, an "affirmation" of white identity (p. 205). Where Troy sees a necessity, Cox exhibits a more pernicious aspect. Pushing his argument, we may conclude that racialized "others" - in this case "Indian spirits" - emerged and were used in the service of whiteness. Utilizing the spirits of the deceased is, then, an example of what

5 The notion of "playing Indian" - which details how whites used constructions of "Indianness" to produce and reinforce a particular "American identity" - offers the opportunity to consider Spiritualism alongside other forms of racialized performance, such as blackface minstrelsy, as Daphne Brooks (2006) and Bridget Bennett (2007) have done. Of course, the concepts of minstrelsy and "playing Indian" invokes the register of performance and spectacle - and, therefore, matters of identification, personification, mimicking — a register that Troy wishes to avoid (2017, p. xxvii). As rationale, Troy offers that mediums believed in "agencies outside of the self;" the framework of performance, she cautions, would necessarily regard all séances and mediums as frauds. This, it seems to me, is an overstatement: conceiving séances as a form of performance does not necessarily refute the veracity of these experiences. Troy, in fact, tacitly acknowledges that séances had a performative aspect when she discusses the presence of "Indian" dress, or costume. Moreover, placing Spiritualist séances in a comparative framework with other racialized performances allows us to see them as part of a wide and diverse set of cultural acts that wrestled with - and reinforcedracialized difference and hierarchy; it allows us to see, too, that "the bodies of spirit mediums," as Brooks writes, operate "as a point of encounter, as an imaginary site of contact and conflict, a frontier on which to locate both 'terror and pleasure"' (2006, p. 27). Brooks takes "terror and pleasure" from Saidiya Hartman's Scenes of Subjection (1997), which argues that minstrelsy and the slave auction block were "sites of performance" where black "suffering was transformed into wholesale pleasures" (p. 32). Brooks analysis is incisive. It also demonstrates the need for a larger range of methods and theories in the study of esoteric idea and practice. I return to this towards the end of the essay. I want to thank Adrienne Rooney for encouraging me to think through this issue. 
Angela Riley and Kirsten Carpenter call "Indian appropriation" (2016). White American Spiritualism, to be sure, did not escape the long, ongoing history of white people appropriating and using the knowledge, practices, artifacts, identities, and bodies of Native Americans for their own benefit (see, among others, Deloria, 1998). Moreover, the temporal nature of the fusion of "red" and "white" reinscribed racial categories, if not hierarchies (see, on this issue, in particular Brooks, 2006). After all, irrespective of how one interprets these stereotypes, it is certain that "unlike white [spirits], Indian spirits bore the attributes of an entire race. Every spirit Indian was, in a sense, Every-Indian, stripped to the essentials" (Cox, 2003, p. 19o; see also Bennett, 2007, p. 99; Troy, 2017, p. 30).

Part of the reason that manifestations of Black Hawk and countless nameless "Indian spirits" often relied on essentialized and racialized cultural representations of Native Americans was that white American Spiritualists interacted to a very limited extent with living Native Americans. Such representations were produced in and reinforced through books written by white authors, such as James Fenimore Cooper's The Last of the Mohicans (1826), and numerous plays (Cox, 2003; Troy, 2017). And while not all representations of Native Americans were the same-Troy (2017, p. 34), for instance, notes that the linguistic representation of "Indian spirits" oscillated between "broken English" and "noble speak," both of which hark back to racialized stereotypes of Native American speech and language - the wide diversity in language, culture, and religion among Native Americans was altogether reduced. What emerged and appeared at the séance table was "the white man's Indian" (McGarry, 2008, p. 67).

With the above in mind, we could ask if the spirits of Lincoln, Montesquieu, Voltaire, and Lee who manifested through members of the Cercle Harmonique were stand-ins for "the" white race. ${ }^{6}$ We should ask, furthermore, if they appeared in a way that presented or depicted an essentialized conceptualization of whiteness. The answer, unsurprisingly, seems to be no. Abraham Lincoln, who appeared at the séance table because of his prominent position in US society and as a "martyr" for abolition (Clark, 2018), simply manifested as himself. In contrast, Black Hawk - even if he retained some of his unique characteristics in spirit (although as noted above, he advanced a message of reconciliation and peace that was rather distant from the message he espoused

6 Or, perhaps, "white races": as Painter (2010, p. ix) argues, Americans have always been convinced of the plurality of "more than one European race," which in and of itself bespeaks a certain privilege afforded to white people that was not afforded to people of color. I return to this below. 
when still alive)—also appeared as "Every-Indian." To better understand why, we need to take into account the destructive and centuries-long history of racialization. Racial stereotyping is wrapped up with power; white people have historically controlled the process of racialization (which includes and is reinforced by racial stereotyping). One of the implications is that white people have named and categorized other peoples into racial groups, whereas whiteness itself has remained unnamed and invisible in the larger public domain (Dyer, 1997). As dominant voices and actors in public domains, white people could introduce a host of different representations of white people and whiteness; the more so, indeed, because whereas white people are seen as individuals, racialized minorities are often treated as an undifferentiated, homogeneous group. White spirits did not appear in an essentialized manner, in other words, because a white hegemony in the public and cultural domain prevented them from doing so.

There is some evidence, however, that essentialized representations of Native Americans did reach the Cercle Harmonique: a Native American spirit named Paloah told the group that the "peace pipe and tomahawk," which she regarded as expressions of "barbarism," were now "buried forever" (Clark, 2016, p. 137). Clark observes that this statement "contained a negative view of Native American religion," but in the context of our discussion above, we can also link this to stereotypical representations of Native Americans. This should come as no surprise: black Americans, too, would have had access to representations of the "white man's Indian." Moreover, even though racialized cultural representations also found way to the séance table in New Orleans, there was a significant difference: in spirit, Poloah was part of an "enlightened" and non-hierarchical "spiritual brotherhood" that included members of all racial groups, nationalities and ethnicities. Whereas white American Spiritualists, by and large, believed that race and nation (and racial hierarchies) remained significant and present in the afterlife, the Cercle Harmonique conceived the spirits that visited with them as "raceless." As Clark writes, "the races of material bodies no longer existed in the spirit world" (2016, p. 136). Racial hierarchies had no place in the spirit world — and should, indeed, have no place in the material world either.

We can begin to make sense of these differing treatments of race in the afterlife when we contextualize them within race relations in the United States. The members of the Cercle Harmonique, as Clark presses over and over, were acutely aware of the ways in which racism continued to shape American life. Even though the members of the group came from a "privileged background" - that is, they were free and educated—racial solidarity and racial equality were immediate, visceral concerns. Consider, for instance, that a week 
and a half after Lincoln's spirit delivered the message with which I opened this section, members of the white supremacist group White League occupied New Orleans - a city that, after the Civil War, witnessed outbursts of racial violence as well as moments of progress - for three days (Clark, 2018, p. 162). As racism continued to segregate the material world, communications with a spiritual, non-hierarchical, egalitarian brotherhood in which race had seemingly ceased to exist helped the Cercle Harmonique to envision a world in which racial hierarchies would be overcome.

The continued and pervasive existence of racial hierarchies had very different implications for white American Spiritualists. In many ways, their push for a more equitable treatment of Native Americans and a "politically non-racial society" was dependent on the racial make-up of the spirits that visited them. After all, it was precisely the fact that these spirits were "Indian" that allowed them to serve as "guides and instructors" in the fight for a more equitable, just society in which Native Americans would become full citizens (Troy, 2017, p. xiii; see also McGarry, 2008, p. 68). In doing so, "Indian spirits" had another function, too: appearing, in particular, in the 186os and 1870s, they often spread a message of a "peaceful relationship" and/or came in the spirit of forgiveness and reconciliation (McGarry, 2008, pp. 78-79; Cox, 2003, pp. 198, 206-8). And many white American Spiritualists were seemingly committed to what we may now call a "post-racial" society. However, that undercurrents of white cultural superiority percolated in their practices, and that they supported policies amounting to assimilation, demonstrates that the "post-racial" is itself racially loaded and highly problematic. Most white American Spiritualists favored the dissolution of individual "tribes" and advocated Anglo-American education (Troy, 2017; McGarry, 2008). Yet, in doing so, as Troy incisively notes, they failed "to realize that instead of establishing a raceless society, they had furthered white hegemony" (Troy, 2017, pp. 147, 149).

In some ways, this blind spot may be the result of the fact that white American Spiritualists remained unaware of the fact that whiteness, too, was a particular, and invented, racialized category. As noted above, since white people had control over the production of racial categories, they could mark others as belonging to a certain race, while inventing themselves as "neutral" or "universal." Whiteness was thereby normative, but simultaneously invisible, unacknowledged, hidden, masked as default, color-free (see Nakayama and Krizek, 1995; Dryer, 1997). This remains commonplace: in fact, the phrase "people of color," although often used, is itself evidence of the continued neutrality of whiteness. In a society marked and demarcated by the color line, whiteness remained a powerful, dominating, yet often unacknowledged and understudied force. 
A century after Black Hawk and Lincoln returned as spirits, in the late summer of 1961, Betty and Barney Hill were on the way back to New Hampshire after a delayed honeymoon in Canada. Driving on a "deserted" road "just south of Lancaster," the couple witnessed something bright in the sky—a star, they initially thought, or a plane, or perhaps a "straying satellite." At some point, it became clear that it was none of these, but a UFO (Fuller, 1966, pp. 6-7). Stepping out of the car and into the field next to the road, Barney saw "at least half a dozen living beings" behind its windows, and immediately "he was certain he was about to be captured" (p. 16). Then, everything went hazy until the Hills were awoken by a beeping sound and realized that they were back in the car, and that Barney was, in fact, driving. Back home, the couple felt "clammy" and "unclean." Barney felt the unexplainable urge to go into the bathroom and examine his "lower abdomen" (pp. 19-20). Upon inspection, the couple realized their shoes were dirty, their watches broken, and Betty's dress ripped. They vowed not to discuss what happened with anyone-and what had, indeed, happened was at that point altogether unclear. However, "uncanny" traces, scary nightmares, and memory gaps compelled Betty, an avid reader of UFO literature, to report it to the National Investigative Committee of Aerial Phenomena (NICAP), in those days the most prominent UFO organization. The NICAP recommended hypnosis, which would become standard procedure in ufology circles.

The Hills' abduction story would become the first reported UFo abduction account in the U.S. The case-which was widely reported by the press, narrated by John Fuller in his bestseller The Interrupted Journey (1966), and made into a TV movie (1975) — served as a kind of blueprint for future UFO abduction narratives. It became the "origin story of the genre" (Lepselter, 2016, p. 65). Indeed, although each UFO abduction account is unique, we can also speak of the existence of a "generic narrative" (Luckhurst, 1998, p. 31; see also Bullard, 1989; Smith, 2001). This narrative has continued to evolve, but Betty and Barney Hill first voiced many of its core elements. These include being taken by unknown gray non-human beings and subjected to medical examinations (among which a pregnancy test), the experience of missing time and memory loss, and the eventual "recovery" of this experience in and through hypnosis.

But what does all this have to do with race? Whereas the manifestation of an "Indian spirit" in "moccasins" in and through a white female medium, or the presence of Abraham Lincoln at the séance table of the Cercle Harmonique, provides a very clear and straightforward starting point for thinking through 
the intersections of race and the esoteric, the Hills' experience-and ufology more generally — offers, at first sight, no such thing. And yet, Barney was black, and Betty was white, at a time when interracial marriages remained illegal in many U.S. states (it became legal across the country in 1967, following the landmark Loving v. Virginia U.S. Supreme Court case). In both popular and academic accounts, however, the interracial nature of their relationship has been mostly mentioned as a curious fact, rather than something that was part, perhaps even constitutive, of the abduction experience (Lepselter, 2012, p. 67). However, when it comes to esoteric phenomena, race shows up and comes to matter in both obvious and obscure ways. If we want to uncover and explore in depth how processes of racialization shape and are informed by esoteric ideas and practice, we also need to look beyond the most clear-cut examples. With the help of Susan Lepselter, Christopher Roth, and Stephen Finley, I will make a case here for the significance of race in the Hills' story, and abduction narratives more generally.

Roth $(2005$, p. 61) takes race seriously when he characterizes the Hills' story as "the suppressed trauma of a mixed-race couple during the civil rights era." Placing their abduction narrative in the context of the history of ufology, Roth sees it as a turning point. Whereas 1950s contactees relied on theosophical ideas "to reerect a toppled racial order"-in particular through their conceptualization of certain extraterrestrials as Aryan-"the Hills story grasps for a position from which white and black Americans can ponder, resolve, and transcend, racial divisions" (p. 61). Race, Roth notes and I concur, has everything to do with it. Consider the following transcript of a hypnosis session, included in Fuller's Interrupted Journey, in which Barney tries to describe what the people behind the window of the Ufo looked like,

DOCTOR: What was his face like? What did it make you think of?

BAR NEY: It was round. (Pauses for a moment, then:) I think of-I think of-a red-headed Irishman. I don't know why. (Another pause, then:) l think I know why. Because Irish are usually hostile to Negroes. And when I see a friendly Irish person, I react to him by thinking: I will be friendly. And I think this one that is looking over his shoulder is friendly. (1966, p. 9o)

And then, a little further:

DостоR: Oh. Did they have faces like other people. You said one was like a redheaded Irishman.

BARNEY: (Describing the scene very slowly and carefully.) His eyes were slanted. Oh-his eyes were slanted! But not like a Chinese. (p. 92) 
These exchanges thus demonstrate that thinking about extraterrestrials very much involves thinking about bodily difference, and, in a racialized "modern West" thus shapes and is informed by processes of racialization (Roth, 2005, pp. 71-4). I do not claim that race determines U Fo abduction experiences (neither does Roth, for that matter), but to suggest that race somehow shaped these experiences seems rather obvious. Importantly, the first exchange cited above highlights that racial hierarchies and racial discrimination inform Barney's conceptualization of otherness. After all, his identification of the extraterrestrial as reminding him of a "red-headed Irishman" is all wrapped up in (racialized) hostility. Considering this, the fact that Barney, after seeing the beings, immediately felt that he would be captured gains heightened significance. In other words, we should ask how this feeling and his racially-inflected description of the extraterrestrials as a "red-headed Irishman" relate.

Race is constitutive of how we conceptualize extraterrestrials. Science fiction scholars have made this claim often. One of the first and still most famous novels about an alien invasion-H.G. Wells's War of the Worlds (1898) - was all about racialized human difference. Writing about an alien invasion from Mars functioned as a fictional outlet for Wells' reflections on the British invasion of Tasmania (Rieder, 2008, p. 5; Kripal, 2017, p. 56). Stories about encounters with extraterrestrials are, as Wells' famous novel also demonstrates, narratives about "us" versus "them" that have the potential to reinscribe if not radicalize the possibility for what Ashon Crawley (2017) and Nahum Chandler (2014) would call "categorical distinctions" that underlie the production of racial categories (see also Rubenstein, 2018). Simultaneously, however, UFO abduction accounts can also transcend these distinctions. Roth (2005, p. 80) calls attention to the fact that in her memoir, Betty Hill conceived the gray beings that abducted her as beings from the future; a future where, ostensibly, racial difference would be transcended, subsumed in all-grey. In "Close Encounters of Diverse Kinds" (2001), a comparative study of UFO abduction accounts and the organization of human difference in and through taxonomy, Jonathan Z. Smith also underscores the greyness of the extraterrestrials to suggest that UFO abduction accounts should be understood as myths that transcend racial categories. The uniformity of alien bodies, Smith writes, is "a striking exaggeration of our commonsense belief (...) that there is an essential core of human sameness" (p. 15). However, Smith too quickly overlooks the extent to which racial categories remain part of UFO abduction accounts, and that abduction accounts also reinscribe racial hierarchies.

If The Interrupted Journey is, as Roth also notes, despite itself a book about race, and if this book served as "blueprint" for all future accounts, then we must ask to what extent UFO abduction narratives are, generally, shaped by 
race. The first thing that stands out, then, is the curious (or perhaps not at all curious) fact that UFO abductions, when perusing academic texts, seem a very white phenomenon - and that, again, this whiteness seems largely understudied. In 2001, Brenda Denzler wrote that Barney Hill was one of only four persons of color who has reported a UFO abduction experience (2001, p. 196n79), and Susan Lepselter's ethnographic research in Arizona confirmed the overwhelming whiteness of ufology communities (2012, pp. 76, 156). However, a lack of reports does not necessarily imply that fewer people of color claim to have been abducted by extraterrestrials. It could be that they are less likely to speak openly about such experiences out of fear of further marginalization, or that their accounts are ignored in the Academy or by the U.S. government. Scholarship on UFOS, moreover, largely ignores the history of African American Ufo traditions, such as the Nation of Islam (Pasulka, 2019, p. 237; Finley, 2016; Kripal, 2017). Studies of Stephen Finley and others have revealed that black people do, in fact, claim to have been abducted. In addition to Louis Farrakhan, leader of the Nation of Islam (Finley, 2012; Lieb, 1998; Bakker, 2013), we may include Prophet Yahweh, Riley Martin (Finley, 2016), and musicians Sun Ra (Szwed, 2012; Youngquist, 2015) and George Clinton (Finley, 2016).

Like in the study of Spiritualism, whiteness emerges as neutral, normative, and universal in the study of UFO abduction accounts. In a short and unpublished "position paper" on Ufos, Finley asks what we may have missed in our exclusive focus on white people (2015). This is an important question that we can ask of much academic research on esoteric phenomena. Finley notes that although Ufos may very well (also) have "universal" meanings and implications, the abduction accounts that he studies do emphasize the "particularity of race." Listing the various experiences of black people who have engaged extraterrestrials (some of whom are mentioned above), Finley posits the possibility of a deep connection between racialized subjectivity and abduction accounts. His interlocutors, he writes, connect their blackness with that of the universe, and as such reconceptualize blackness as "metaphysical." For these abductees, moreover, "aliens" are not the ultimate "other," but rather "kin." Finley links UFO abduction accounts to the transatlantic slave trade, framing white slavers as an "alien presence" that abducted black "bodies" - at which point, he notes, they in turn became an "alien presence" in the United States. This observation gains heightened significance when we take note of scholarship in black studies that demonstrates that what is at stake in conversations about race and racial difference is not merely a "social construct" or the topic of "identity," but a matter of who is considered to be "fully human" (see among others Fanon, 1952; Moten, 2008; 2013; Sharpe, 2016; Spillers, 1987; Weheliye, 2014; Wynter, 2003; 2015). It is important to keep this in mind when we assess 
and analyze the intersections between whiteness and (the study of) esotericism, as this underscores just how significant race and processes of racialization are in and to our current social order.

Finley's work helps me to emphasize that although the power to racialize has lain, historically, with white people, people of color have utilized esotericisms to produce new racial formations (for important examples, see Finley, Guillory and Page, 2015; Weisenfeld, 2016). But his provocations prompt, for me, also a question. If there is a link-experientially and epistemologicallybetween blackness and abduction, then what can we make of the fact that most of the abduction accounts that we have access to are reported by white people? What have we missed by ignoring race in the reports that we do study, in which white people claim to have been abducted? Racial constructs and racial hierarchies inform UFO abduction accounts. They also shape the way they have been studied: the questions asked or ignored, and the frameworks deployed or rejected.

One possibility, voiced by Roger Luckhurst (1998, p. 44) in an article that understands alien abduction narratives as the "science fictionalization of trauma" is that these stories - among many other things—allegorize "the foundation of America," which was built via "the abduction of Africans into slavery." The general tropes of these accounts-abductees are often restrained before they are transported to the space ship, undergo a variety of medical tests (often related to reproduction, such as the harvesting of sperm or eggs), have reported experiences of sexual assault, speak of "missing time," and believe their "hybrid" children to be stolen by aliens - are, to be sure, eerily similar to (although also displaying significant differences from) the experiences of enslaved Africans. Radicalizing Luckhurst's proposal, Adam Roberts suggests that we should understand UFO abduction experiences as a kind of "return of the repressed." With recourse to Freud's theory of repressed memory, he posits the possibility that although the narrative of American progress and success seeks to push "eighteenth and nineteenth century slaving" to the realm of the "political unconsciousness," it resurfaces in alien abduction narratives (2006, p. 106). In so doing, "mainstream America (...) interpolat[es] itself into the victim role" (ibid.).

Susan Lepselter's ethnographic research allows us to make the connections between UFO abduction experiences and America's traumatic past more explicit and tangible. In The Resonance of Unseen Things (2016) she jots down the many times that she's heard white people who experienced alien abductions reflect on the fact that to Native Americans, white people would have been an alien presence (p. 67). "We invaded their land," one of them notes - a twenty-first century statement that takes us right back to Wells' late 
nineteenth-century story. A flyer, handed to Lepselter during a UFO meeting, makes the connections even more clear, if also all the more ambiguous: "Do you have an interest in Native Americans, or maybe some Native American blood? It could be a sign that you've been abducted by aliens" (p. 78). Lepselter does not elaborate on the precise meaning or implication of this specific flyer but it is worth noting that connecting "abduction" by "aliens" with "Native American blood" seems to imagine a particular and rather uncomfortable intimacy or proximity between Native Americans and abduction. For Lepselter, such statements are part of a complex narrative of guilt and desire, appropriation and concern, commodification and interest.

How should we read these links between alien invasion and colonization in the context of our topic at hand? Lepselter writes about a "friend" from the "Hillview ufo Experiencers Group" who moved to Arizona, in part, to "be near Indians." A more charitable reading could thus suggest that one of the "outcomes" of alien abduction narratives is that white people become more interested in past and present Native American life and religion-even if, as Lepselter also makes clear, this interest is commodified and borders on appropriation. Rather than engaging living Native Americans, this informant ended up meeting like-minded white people (2016, p. 75). Here, whiteness recenters itself.

This brings me to another, admittedly more cynical reading. As UFO abduction narratives gain more and more prominence-in the public domain, in writings, in films, on TV-white people essentially replace Native Americans as the prime targets of invasion and abduction. In doing so, the prominence of white UFO abduction accounts trivializes, indeed erases, the traumatic pasts of Native Americans and black Americans, who are doubly displaced when we consider, once more, that their accounts are ignored. Here we see, again, the power of whiteness to not merely present itself as neutral and universal, but also (indeed therefore) to appropriate, claim, and own. This observation gains, in turn, heightened significance when we consider that white rights and demands to property and ownership were often developed and exercised in relation to the (continued) disenfranchisement, displacement, and dehumanization of African Americans and indigenous peoples (see, for example, Harris, 1993; Bhandar, 2018).

\section{A Final Note on Method and Theory}

The studies discussed in this essay demonstrate that Spiritualism and UFO abduction accounts have a racialized history. When we consider that some of 
these publications are older than fifteen years, we must conclude that we have known this for quite a while. But this has seemingly not (yet) compelled scholars in the field of (Western) esotericism to embrace race as a critical category of analysis, a fact that becomes particularly curious when we consider that Spiritualism now plays a central role in the "canon" of Western esoteric traditions. We must ask, in other words, why the study of esotericism privileges certain peoples, texts, ideas, themes and perspectives over others, a question that points us to persistent power imbalances, inequalities, and practices of "othering" (see also Bakker, 2020). Part of the reason for this neglect is the overwhelming but unrecognized, unacknowledged, and understudied whiteness of the field (Bakker, 2020; see also Finley, Guillory and Page, 2015). It seems as if most scholars in Western esotericism were (or are) largely unaware that whiteness is a racial category. This has allowed for a situation in which scholarship in the field focuses on white esoteric ideas and practices, yet does not investigate how (constructions of) whiteness shape and operate in (the study of) esoteric ideas and practice. As a result, dominant themes, concepts, and frameworks in the field are structured around what Sylvester Johnson, in a different context, would call a "core of white subjectivity" (2009, p. 16o).

With the survey presented above in mind, I want to suggest here a second, if very much intertwined reason for the lack of research on the intersections of race and esotericism: a limited engagement with fields, approaches, discourses and texts in which race is a focal point of analysis. The scholars cited above come from a wide variety of fields: Christopher Roth and Susan Lepselter approach the UFO movement from anthropology; Bridget Bennett operates within the domain of literary, and more specifically, Victorian studies; Molly McGarry and Kathryn Troy are historians; and Emily Suzanne Clark works in American Religion. Yet all display an acute understanding of how race works and operates in American history and society, revealing an implicit (and often explicit) indebtedness to critical race theory. It seems to me possible, if not likely, that their scholarship was overlooked because of a "negative heuristic" (to use Egil Asprem's term, 2014, p. 15) that encouraged a refusal to engage texts with a specific, and theoretical, focus on race. That the field of Western esotericism works with a rather limited set of methods and theoriesmainly historical methods and textual analysis - has been remarked by other scholars (Crockford and Asprem, 2018, p. 2; Asprem, 2014, p. 19; Finley, Guillory and Page, 2015a, pp. 1-3). In some cases, scholars even displayed an explicit aversion for "cultural studies" and "critical theory" (e.g. Hanegraaff, 2019; cf. Strube, 2021). And while this narrow methodological scope is certainly changing - consider, for instance, recent special issues on esotericism and cognitive science (in Aries) and esotericism and ethnography (in Corre- 
spondences) - several frameworks and approaches remain understudied and underrepresented, among which frameworks and approaches developed in decolonial, ethnic, black, and whiteness studies (see, for an exception, Gray, 2019).

At the risk of stating the obvious, I posit furthermore that the limited engagement with these approaches in the study of esotericism is, in itself, racialized: working from a privileged position in which whiteness is seen as normative and neutral, if not universal, scholars have not been forced to engage with race, and have not been encouraged to confront that whiteness is a racialized category that demands careful scrutiny. Although whiteness studies first came to Europe in the 199os, when the field of Western esotericism was still in its infancy, scholars could ignore it because they had not been forced to engage scholarship that thinks critically and carefully about whiteness and race. The overwhelming whiteness of the field and the limited amount of methodologies engaged are connected.

Recent years have witnessed a number of publications of scholars working in the field of (Western) esotericism that do engage race-and more are in the pipeline. It is my hope that these works intensify the much-needed diversification of methods in the field. After all, embracing race as an analytical category in the field of (Western) esotericism demands not only an awareness of the racial diversity of esoteric belief and practice, but also a rigorous and sustained engagement with frameworks developed in fields such as black studies, ethnic studies, whiteness studies, and critical race theory.

\section{Bibliography}

Alexander, M. (2010) The New Jim Crow: Mass Incarceration in the Age of Colorblindness. New York: The New Press.

Asprem, E. (2014) "Beyond the West: Toward a New Comparativism in the Study of Esotericism," Correspondences, 2(1), pp. $3^{-33}$.

Bakker, J.M. (2013) 'On the Knowledge of God, Self and Enemy': Secrecy, Concealment, and Revelation in the Nation of Islam," Unpublished MA thesis, University of Amsterdam.

Bakker, J.M. (2020) "Hidden Presence: Race and the History, Construct and Study of Western Esotericism," Religion, 5o(4), pp. 479-503.

Bennett, B. (2007) Transatlantic Spiritualism and Nineteenth-Century American Literature. Manchester: Manchester University Press.

Berry, C. (1876) Experiences in Spiritualism. London: James Burns. 
Bhandar, B. (2018) Colonial Lives of Property: Law, Land, and Racial Regimes of Ownership. Durham: Duke University Press.

Bonilla-Silva, E. (2003) Racism Without Racists: Color-blind Racism and the Persistence of Racial Inequality in the United States. Lanham: Rowman \& Littlefield.

Brooks, D. (2006) Bodies in Dissent: Spectacular Performances of Race and Freedom, 1850-1910. Durham: Duke University Press.

Bullard, T.E. (1989) "UFO Abduction Reports: The Supernatural Kidnap Narrative Returns in Technological Guise," Journal of American Folklore, 102, pp. 147-170.

Chandler, N. (2014) X: The Problem of the Negro as a Problem for Thought. New York: Fordham University Press.

Clark, E.S (2016) A Luminous Brotherhood: Afro-Creole Spiritualism in NineteenthCentury New Orleans. Chapel Hill: University of North Carolina Press.

Clark, E.S. (2018) “'To Battle for Human Rights': Afro-Creole Spiritualism and Martyrdom," Journal of Africana Religions, 6(1), pp. 161-189.

Coleman, B. (1861) Spiritualism in America. London: F. Pitman.

Cox, R.S. (2003) Body and Soul: A Sympathetic History of American Spiritualism. Charlottesville: University of Virginia Press.

Crawley, A.T. (2017) Blackpentecostal Breath: The Aesthetics of Possibility. New York: Fordham University Press.

Crockford, S. and Asprem E. (2018) "Ethnographies of the Esoteric: Introducing Anthropological Methods and Theories to the Study of Contemporary Esotericism," Correspondences, 6(1), pp. 1-23.

Denzler, B. (2001) The Lure of the Edge: Scientific Passions, Religious Beliefs, and the Pursuit of UFOs. Berkeley: University of California Press.

Du Bois, W.E.B. (1903) The Souls of Black Folk. Chicago: A.C. McClurg \& Co.

Fanon, F. (1952) Black Skin/White Masks. New York: Grove Press.

Ferguson, C. (2012) Determined Spirits: Eugenics, Heredity and Racial Regeneration in Anglo-American Spiritualist Writing, 1848-1930. Edinburgh: Edinburgh University Press.

Finley, S.C. (2012) “The Meaning of Mother in Louis Farrakhan's "Mother Wheel”: Race, Gender, and Sexuality in the Cosmology of the Nation of Islam's UFO," Journal of the American Academy of Religion, 8o(2), pp. 434-465.

Finley, S.C. (2015), "UFOs: A Position Paper," presented at "Beyond the Spinning: Shifting the Conversation around the UFO Phenomenon," a symposium sponsored by the Center for Theory and Research, Esalen Institute, at Institute of Noetic Sciences, Petaluma, California, September 11-13, 2015.

Finley, S.C. (2016) "The Supernatural in the African American Experience," in Kripal, J.J. (ed.) Religion: Super Religion. New York: Macmillan Reference USA, pp. 231-46.

Finley, S.C., Guillory, M.S., and Page Jr., H.R. (eds.) (2015) Esotericism in African American Religious Experience: "There is a Mystery, Leiden: Brill. 
Fuller, J.G. (1966; 1967) The Interrupted Journey: Two Lost Hours 'Aboard a Flying Saucer'. New York: Dial Press.

Goldberg, D.T. (2015). Are We All Postracial Yet? New York: Polity Press.

Goodrick-Clarke, N. (1985) The Occult Roots of Nazism: Secret Aryan Cults and Their Influence on Nazi Ideology. New York: New York University Press.

Goodrick-Clarke, N. (2003) Black Sun: Aryan Cults, Esoteric Nazism and the Politics of Identity. New York: New York University Press.

Granholm, K. (2013) "Locating the West: Problematizing the Western in Western Esotericism and Occultism," in Bogdan, H. and Djurdjevic G. (eds.) Occultism in a Global Perspective. London/New York: Routledge, pp. 17-36.

Gray, B. (2019) "The Traumatic Mysticism of Othered Others: Blackness, Esotericism, and Islam in the Five Percenters," Correspondences, 7(1), pp. 201-238.

Guillory, M.S. (2018). Spiritual and Social Transformation in African American Spiritual Churches. New York: Routledge.

Hanegraaff, W.J. (2019) "Rejected Knowledge...So You Mean That Esotericists Are the Losers of History?" in Hanegraaff, W.J., Forshaw, P., and Pasi, M. (eds.) Hermes Explains: Thirty Questions about Western Esotericism. Celebrating the 2o-Year Anniversary of the Centre for History of Hermetic Philosophy and Related Currents at the University of Amsterdam. Amsterdam: Amsterdam University Press, pp. $145^{-52 .}$

Harris, C. (1993) "Whiteness as Property," Harvard Law Review, 106(8), pp. 1707-1791.

Hartman, S. (1997) Scenes of Subjection: Terror, Slavery and Self-Making in NineteenthCentury America. New York: Oxford University Press.

Johnson, S.A. (2009) "Religion Proper and Proper Religion: Arthur Fauset and the Study of African American Religions," in Curtis IV, E.E. and Brune Sigler, D. (eds.) The New Black Gods: Arthur Huff Fauset and the Study of African American Religions. Bloomington: Indiana University Press, pp. 145-70.

Knight, M.M. (2019) "I am Sorry, Mr. White Man, These are Secrets that You are Not Permitted to Learn': The Supreme Wisdom Lessons and Problem Book," Correspondences, $7(1)$, pp. 167-200.

Kripal, J.J. (2017) Secret Body: Erotic and Esoteric Currents in the History of Religions. Chicago: University of Chicago Press.

Lepselter, S. (2016) The Resonance of Unseen Things: Poetics, Power, Captivity, and UFOs in the American Uncanny. Ann Arbor: University of Michigan Press.

Lieb, M. (1998) Children of Ezekiel: Aliens, UFOs, the Crisis of Race, and the Advent of End Times. Durham: Duke University Press.

Lloyd V.W. (2016) "Managing Race, Managing Religion," in Khan, J.S. and Lloyd, V.W. (eds.) Race and Secularism in America. New York: Columbia University Press, pp. 1-21.

Luckhurst, R. (1998) "The Science-Fictionalization of Trauma: Remarks on Narratives of Alien Abduction," Science Fiction Studies, 25(2), pp. 29-52. 
Marable, M. and Agard-Jones, V. (eds.) (2008) Transnational Blackness: Navigating the Global Color Line. New York: Palgrave MacMillan.

McGarry, M. (2008) Ghosts of Futures Past: Spiritualism and the Politics of NineteenthCentury America. Berkeley: University of California Press.

Moten, F. (2008) “The Case of Blackness," Criticism, 5o(2), pp. 177-218.

Moten, F. (2013) "Blackness and Nothingness (Mysticism in the Flesh)," The South Atlantic Quarterly, 112(4), pp. 737-8o.

Nakayama, T.K. \& Krizek, R.L (1995). "Whiteness: A Rhetoric," Quarterly Journal of Speech, 81(3), pp. 291-309.

Omi, M. and Winant, H. (1994) Racial Formation in the United States: From the 196os to the 199os. New York: Routledge.

Owen, A. (1989) The Darkened Room: Women, Power and Spiritualism in Late Victorian England. Chicago: Chicago University Press.

Painter, N.I. (2010) A History of White People. New York: W.W. Norton \& Company.

Pasi, M. (2010) "Oriental Kabbalah and the Parting of West and East in the Early Theosophical Society," in Huss, B., Pasi, M., and Stuckrad, K.v. (eds.) Kabbalah and Modernity: Interpretations, Transformations, Adaptations. Leiden/Boston: Brill, pp. 151-66.

Pasulka, D.W. (2019) American Cosmic: UFOs, Religion, Technology. Oxford: Oxford University Press.

Polk, P. (2010) “'He Will Remember Me': Anglo-American Spiritualists, Slavery, and the Ghosts of Miscegenation." Southern Quarterly, 47(4), pp. 24-42.

Rieder, J. (2008) Colonialism and the Emergence of Science Fiction. Middletown: Wesleyan University Press.

Riley, A.R. and Carpenter, K.A. (2016) "Owning Red: A Theory of Indian (Cultural) Apprpriation," Texas Law Review, 94, pp. 859-931.

Roberts, A. (2004) Science Fiction (Second Edition). London: Routledge.

Roth, C.F. (2005) "Ufology as Anthropology: Race, Extraterrestrials, and the Occult," in Battaglia, D. (ed.) E.T. Culture: Anthropology in Outer Spaces. Durham: Duke University Press, pp. $3^{8-93 .}$

Roukema, A. and Kilner-Johnson, A. (2018) "Editorial: Time to Drop the 'Western," Correspondences, 6(2), pp. 1-7.

Rubenstein, M.-J. (2018) Pantheologies: Gods, Worlds, Monsters. New York: Columbia University Press.

Sharpe, C. (2016) In the Wake: On Blackness and Being. Durham: Duke University Press. Silva, D.F.d. (2007) Toward a Global Idea of Race. Minneapolis: University of Minnesota Press.

Smith, J.Z. (2001) “Close Encounters of Diverse Kinds," in Muzruchi, S.L. (ed.) Religion and Cultural Studies. Princeton: Princeton University Press, pp. 3-21.

Spillers, H.J. (1987) “Mama's Baby, Papa's Maybe: An American Grammar Book," Diacritics, $17(2)$, pp. $64-81$. 
Staudenmaier, P. (2014) Between Occultism and Nazism: Anthroposophy and the Politics of Race in the Fascist Era. Leiden: Brill.

Strube, J. (2021) “Towards the Study of Esotericism without the 'Western": Esotericism from the Perspective of a Global Religious History," in Asprem, E. and Strube, J. (eds.) New Approaches to the Study of Esotericism. Leiden and Boston: Brill, pp. $45^{-66 .}$

Strube, J. (2016) "Transgressing Boundaries: Social Reform, Theology, and the Demarcations between Science and Religion," Aries, 16(1), pp. 1-11.

Szwed, J. (2012) Space is the Place: The Life and Times of Sun Ra. New York: Knopf Doubleday Publishing Group.

Troy, K. (2017) The Specter of the Indian: Race, Gender, and Ghosts in American Seances, 1848-189o. New York: SunY Press.

Weheliye, A.G. (2014) Habeas Viscus: Racializing Assemblages, Biopolitics, and Black Feminist Theories of the Human. Durham: Duke University Press.

Wehmeyer, S. (2010) "Marching Bones and Invisible Indians: African American Spiritualism in New Orleans, Past and Present," Southern Quarterly, 47(4), pp. 43-6o.

Weisenfeld, J (2016) New World A-Coming: Black Religion and Racial Identity During the Great Migration. New York: New York University Press.

Wynter, S. (2003) "Unsettling the Coloniality of Being/Power/Truth/Freedom: Towards the Human, After Man, Its Overrepresentation-An Argument," CR: The New Centennial Review, 3(3), pp. 257-337.

Youngquist, P. (2016) A Pure Solar World: Sun Ra and the Birth of Afrofuturism. Austin: University of Texas Press. 